\title{
Az innováció lehetséges hatása a sportágak versenyképességére
}

\section{Potential Impact of Innovation on the Competitiveness of Sports}

\section{T. MADARÁSZ}

Debreceni Egyetem, Gazdaságtudományi Kar, Sportgazdasági-és Menedzsment Intézet, madarasz.tamas@econ.unideb.hu

Kivonat: A sportágakhoz kapcsolódó innovációs és fejlesztő tevékenységek, illetve a folyamatok során létrejövő eszközök elősegítik a teljesítménykényszerben lévő sportági szereplőket (sportoló, edző, sportvezető), hogy szakágukban kiemelkedö eredményeket érjenek el.

A sportági eredményesség nagymértékben kihathat a sportágak társadalmi megítélésére és a gazdasági potenciáljukra, ezáltal a szakágak jövőjére is. Tanulmányomban arra vállalkozom, hogy bemutassam a versenysporthoz kapcsolódó innovációs folyamatokat, továbbá ezen újító tevékenységek során létrejövő termékeket, majd megvizsgáljam, hogy ezen kellékek hogyan és milyen mértékben befolyásolják a vizsgált sportágak gazdasági és sportszakmai eredményességét.

Kulcsszavak: sportgazdaság, sportinnováció, sportszakmai sikeresség, sportgazdasági sikeresség, versenyképesség

Abstract: Innovation and development activities related to sports and the tools created during the processes facilitate performance sports players (athlete, coach, sports manager) to achieve outstanding results in their field.

The success of sport can have a major impact on the social image of sport and its economic potential, and thus on the future of the sport. In my paper, I undertake to introduce the innovation processes associated with competitive sport and the products that result from these innovative activities, and then examine how and to what extent these supplies influence the economic and professional performance of the sports under investigation.

Keywords: sports economy, sports innovation, sports professional success, sports economy success, competitiveness 


\section{A kutatás célkitűzései}

A kutatás során célom, hogy bemutassam és megvizsgáljam, hogy a különböző sportinnovációs folyamatok során létrejövő és kialakuló új eszközök, illetve termékek hogyan és milyen mértékben befolyásolják a sportágakban „születő” eredményeket. Azt feltételezem, hogy az innovatív termékek elősegítik a sportolók teljesítőképességének a javulását, ezáltal a kiemelkedő eredményeket elérő sportolók nagyobb média érdeklődést generálnak saját maguknak és a sportáguknak is, ezáltal ezen személyek véleményvezérekké, míg a választott sportágaik versenyképesebbé válnak. A kutatás során arra is keresem a választ, hogy a sokszor emberfeletti teljesítmény hatására nő az adott sportág vagy sportoló ismertsége, ezáltal az „értéke” is? És végül célom megvizsgálni, hogy előidézheti-e ez a népszerűség növekedés a sportágak nézettségének az emelkedését?

\section{Szakirodalmi áttekintés}

Jelen fejezetben a sportszakmai és a sportgazdasági siker definiálásán túl arra vállalkozom, hogy bemutassam az innovációs fejlesztéseket és az azoknak köszönhető kiemelkedő eredményeket. A sikeresség növeli a sportágak médiában való jelenlétét, így azok versenyképességét is [1]. A szakirodalmi áttekintésben ismertetem a versenyképesség és az innováció fogalmát, majd kitérek a sport versenyképességére és a tanulmányban választott sportágak történetében megjelenő innovációs eszközökre.

A versenyképességi vizsgálatok során az innováció fogalmával több ízben találkozhatunk. Az utóbbi időben a sport önálló nemzetgazdasági ágazattá vált, így a sportinnováció fogalma is egyre inkább előtérbe kerül [2]. A versenyképesség egy relatív mérőszám [3], napjaink egyik leggyakrabban használt fogalma [4]. Számos kutató foglalkozik a versenyképesség elméleti hátterével és mérési lehetőségeivel [5]. A definíció és a mutatószámok tekintetében azonban nem létezik közöttük egységes álláspont [6]. A versenyképesség relatív fogalma vállalati szinten annak a képessége, hogy szembenézhessünk a versennyel, és akkor legyünk sikeresek, mikor erre sor kerül. Továbbá annak a képessége, hogy el tudjuk adni a termékeket, amelyek iránt kereslet van (ár, minőség, mennyiség), ami idővel profitot és vállalkozási növekedést biztosíthat [7]. A szerző [8] három versenyképesség típust határoz meg: 1.erőforrás alapú, 2. hatékonyság alapú, 3. innováció alapú versenyképesség. Jelen tanulmányban csak a 3., vagyis az innovációval kapcsolatos versenyképességet használom. Porter szerint az innováció hatására a nemzetgazdasági versenyképesség kiindulópontjává a kapacitások és az előállítási tényezők állandó jellegű megújítása válik [9].

\subsection{Versenyképesség a sportban}

A nemzetgazdasági versenyképességet a sportban kétféleképpen értelmezhetjük, nemzetgazdasági sportszakmai versenyképességként, és nemzetgazdasági szintű sportgazdasági versenyképességként [10]. Azt a területet tekinthetjük a sport terén versenyképesnek, amely a rendelkezésre álló erőforrásokat olyan sporteredménnyé alakítja, mely alkalmas a folyamatosan 
fejlődő, magas igényeket támasztó világpiaci kereslet kielégítésére [11]. A sportban egyre kiélezettebb a verseny a fogyasztók idő- és pénzráfordításáért, az üzleti szféra figyelméért és az állam szervezeti, jogi és pénzügyi támogatásért [12]. A hivatásos sportban is egyre inkább központi kérdéssé vált az, hogy mennyire szórakoztató [13].

A sportágak rendszerében talán csak a tenisz, illetve a labdarúgás tartoznak azon olimpiai sportágak közé, amelyeknek nem a nyári ötkarikás játékok számítanak a legnagyobb sporteseménynek. A többi olimpiai sportágnak a négyévente megrendezésre kerülő globális viadal a fő versenyhelyszíne.

A játékokon megszerzett érmek és pontszerző helyezések alapján határozható meg a sportszakmai versenyképesség mértéke. A Nemzetközi Olimpiai Bizottság (NOB) a nemzetek eredményességének meghatározása során a játékokon elért sikereket veszi alapul.

„A sportágaknak szükséges egyrészt a versenyben történő sikeres helytállás, másrészt elengedhetetlen a versenyben való minél komplexebb alkalmazkodás is. Azok a sportágak tekinthetők versenyképesnek, amelyek ezen tényezők maximalizálására törekednek miközben versenyben állnak versenytársaikkal" [1].

\subsection{Az innováció, mint a versenyképesség egyik meghatározója}

A megújulás az innováció során szinte kivétel nélkül megjelenik. Az innováció fogalmi lehatárolása: „az innováció egy ötlet átalakulása vagy a piacon bevezetett új, illetve korszerúsített termékké, vagy az iparban és kereskedelemben felhasznált új, illetve továbbfejlesztett műveletté, vagy valamely társadalmi szolgáltatás újfajta megközelítése." [14]

Porter szerint a versenyképesség fő eleme a termelékenység. A termelékenység növekedése a fenntartható versenyképesség egyik jelentős eleme, továbbá nagymértékben kapcsolódik az új technológiák vagy más újítások, innovációk bevezetéséhez. Az innováció fontosságára több szerző is felhívja a figyelmet. A 21. században csak az a vállalat lehet igazán versenyképes, amely beruház az innovációba és az újításaival folyamatosan növeli a versenyelőnyét [15]. Az innováció nagy ellensége a jelen sikere, hiszen az eredményes vállalatnak úgy kell a fejlődéshez szükséges stratégiáját módosítani, hogy az az aktuális termelést negatívan ne befolyásolja [16]. Három alapvető versenyelőny alakult ki, amelyeket a versenyképesség forrásainak kell tekintenünk. Az alapvető három versenyelőnynek a volument, a rugalmasságot és az innovációt tekinti [17].

\subsection{A sport, mint önálló iparág}

A sport mára a szórakoztató ipar szerves része, ahol a látványosság, az izgalom és a kiszámíthatatlanság egyre inkább előtérbe kerül [11]. A mai felgyorsult és ingerekkel teli világban az unalmas események könnyen érdektelenségbe, kudarcba fulladhatnak. Ennek érdekében a sportágak szabályozói nagy erőkkel keresik és építik be a minél látványosabb elemeket a képviselt sportágukba. Szükséges, hogy a közvetített sportesemény képi világával fel tudja venni a versenyt az egyéb médiagépezet által gyártott tartalmakkal, vagyis a sporttevékenységnek versenyeznie kell más szabadidős tevékenységekkel (televízió, mozi, színház stb.). Minél inkább képes egy 
sportág megfelelni a médiaképesség feltételrendszerének, annál előnyösebb pozíciót foglal el a versenyképességi rangsorban.

A sportgazdaság egésze általában nem egy külön mért szektor, hanem számos más iparág és gazdasági ágazat része. „Olyan iparági ágazat, amely sportszolgáltatásokat állít elő és visz a fogyasztói piacra." [2]. Az A.T. Kearney menedzsment tanácsadó cég 2014-ben közölt tanulmányában kifejti, hogy a világ sportágazata ma nagyjából 450 milliárd euró értékü, amely piacban rengetegen vesznek részt, és ez a hatalmas gépezet kiterjed többek között a sporteseményre, a rendezvény során jelen lévő élelmiszerekre és a stadionokban megvásárolható emléktárgyakra, továbbá a médiajogokra és a szponzorálásra is.

A sportesemények piaca egyre növekszik. Egy négyéves ciklus a sportesemények számát és típusát tekintve konstansnak tekinthető, hiszen ezen időszak alatt rendeznek egy nyári és egy téli olimpiát, illetve labdarúgó világ-és kontinens bajnokságokat is. 2009 és 2013 között a sportpiaci bevételek 18 milliárd dollárra nőttek, amely 7\%-os összetett éves növekedési rátát jelentett ebben az időszakban. Ez a szám azt jelenti, hogy a sportpiac gyorsabban nőtt, mint a GDP szinte minden országban a világon, ráadásul az igazán nagy piacokon (Egyesült Államok, Brazília, Kína, Egyesült Királyság, Franciaország) ennél még magasabb mértékben emelkedett [18].

A sportot az egész világon kiemelkedő ipari ágazatnak tekintik, főleg a versenysport, a rekreáció, a fitnesz és a szórakoztatóipar területén. Ezeket a területeket a digitális technológia figyelemre méltóan átalakította [19]. A sportiparág bevételei folyamatosan növekednek, hiszen míg 2009ben 58,4 milliárd dollár volt, addig 2013-ban már 76,1 milliárd dollár. Ráadásul 2012-ben - a londoni ötkarikás játékok és az ukrán-lengyel közös rendezésű labdarúgó Európa bajnokság évében - ez az összeg 78,2 milliárd dollárt is elérte [18].

Európában a Közel-Keleten és Afrikában hatalmas fölénnyel vezet a labdarúgás (27,1 milliárd USD), míg Dél-Amerikában (4 milliárd USD) és Ázsiában (3,6 milliárd USD) szerényebb mértékben szerepel az élen. Észak-Amerikában azonban az „európai” labdarúgás volumene elenyésző a hagyományos amerikai sportágakkal (amerikai foci, kosárlabda, baseball, jégkorong) szemben, amelyek bevétele 26,3 milliárd USD volt 2014-ben. A Forma-1 földrészünkön 2,7 milliárd USD, míg Ázsiában 1,5 milliárd USD bevételt generált. A tenisz csak Észak-Amerikában 0,9, Európában a Közel-Keleten és Afrikában 1,2, Ázsiában 0,6, míg Dél-Amerikában 0,3 milliárd USD eredményt termelt. A golf Észak-Amerikában 1, illetve Európában a Közel-Keleten, illetve Afrikában 0,6 milliárd USD-t indukált.

\subsection{Néhány „csodaeszköz” a történelemben}

A legtöbben azt gondolhatjuk, hogy az innováció során létrejövő eszközök csak az utóbbi pár évben esetleg évtizedben segítik a sportolókat. A fejlődést valóban elősegíti az utóbbi időszakban tapasztalható jelentős technikai forradalom, ahol sokkal gyorsabban, egyszerúbben és nem utolsó sorban olcsóbban állíthatók elő a „forradalmi” eszközök. A kiemelkedő produktumok létrejöttét továbbá az is segíti, hogy manapság már a tervezés során - a különböző szoftveres és IT eszközök segítségével - képesek a fejlesztők az egyes innovációs ötletek átültetésére a gyakorlatban, így nem minden esetben szükséges a próbadarabokat ténylegesen létrehozni. Azonban nem volt ez 
mindig így, ezért az alábbi fejezetben szeretnék bemutatni pár sporteszközt bemutatni a történelemben.

\subsection{1. „Csavaros” stoplis cipő (1954)}

A cipőt, melynek a talpán találhatóak „tapadást” segítő kiszögelések már 1526-ban is készítettek. Az első sportcélú szöges cipőt 1891-ben alkalmazták, előtte a korai játékosok csak a munkás cipőjükben sportoltak (footballhistory.org). A csavarozható változat az 1954-es Bern-i labdarúgó világbajnokság döntője során került először a német labdarúgók lábára. Az Adidasalapító Adi Dassler által készített cipő óriási előnyt jelentett az NSZK játékosai számára, akik 3:2 arányban győzték le az óriási favoritnak számító magyar csapatot és lettek világbajnokok. Dassler találmányával a német játékosok a felázott talajú pályán jóval könnyebben tudtak mozogni és irányt váltani, ezáltal előnyben voltak az Aranycsapattal szemben. A cipő előnyét mi sem bizonyítja jobban, hogy a magyar csapat a csoportmérkőzések során könnyűszerrel 8:3 arányban győzte le a későbbi világbajnok csapatot. Ez a mérkőzés volt az, amelynek hatására elterjedtek a stoplis cipők a világon.

\subsubsection{A cápadressz (2008-2010)}

A legismertebb innovációs sporteszköz az úszóknál 2008-2010 között alkalmazott cápadressz volt, amelynek köszönhetően hihetetlen, szinte már emberfeletti rekordok dőltek meg az úszósportban. A ruha lényege, hogy a lehető legnagyobb felületen takarta az úszók testét, ezáltal egy második bőrréteget képzett az úszókon. A szűk és szoros ruha egyrészt nagy mértékben csökkentette a közegellenállást, másrészt fokozta a vérkeringést, amely még inkább elősegítette a kiemelkedő teljesítményt. „Amikor rájöttek, hogy mindezzel több tizedmásodpercnyi előnyt lehet nyerni, és hogy egy jó dresszben egy kevésbé tehetséges úszó képes legyőzni az egyébként nála erôsebb társát, a Nemzetközi Úszószövetség betiltotta a ruhák viselését" [20]. A SPEEDO LZR RACER úszóruhát több, mint 400 elit úszóval tesztelték és megállapították, hogy minimum 5\%-kal nagyobb hatékonyságot jelent az úszók számára a medencében ${ }^{1}$ [21].

\subsubsection{Síugró ruha (2015-2017)}

A síugrás - bár első ránézésre nem úgy tűnik - technikai sportágnak számít. A szabályait legegyszerübben úgy lehet bemutatni, hogy a portolók lesiklanak egy sáncon, amelynek a végén (a „sáncasztalon”) elrugaszkodnak, annak érdekében, hogy a lehető legmesszebbre repüljenek a levegőben. A sílécek waxolásából kiindulva, - amelytől az könnyebben siklik a sáncon - a sícipők kötésein át egészen a síugró ruhájáig terjedhetnek a fejleszthető területek. A nagyobb légellenállás hosszabb idei tartja a magasban az ugrót, amelynek köszönhetően hosszabb távon képes „repülni” a levegőben. Bár a síugrás pontozásakor a távolság csak az egyik összetevő, növelésével könnyedén lehet előnyt szerezni a versenytársakkal szemben. A síruha tekintetében elég csak egy

\footnotetext{
${ }^{1}$ A SPEEDO ruhája 10\% -kal kevésbé passzív húzással rendelkezik (ami azt jelenti, hogy az úszás merülés vagy fordulás után a vízen átcsúszik), mint a Speedo 2004-es FASTSKIN FSII és 5\% -kal kevésbé passzív húzással, mint a FASTSKIN FS-PRO. Az utóbbi ruhával 21 úszó állított fel világrekordot a 2007. március és 2008 között. Forrás: [20].
} 
pár centiméterrel nagyobb ruha, amely például a hónaljaknál vagy a lábak között nagyobb felületen képes felfogni a levegőt. A FIS (Nemzetközi Síszövetség) síugás szakágával kapcsolatban a döntéshozók szabályozták a sportolók által viselhető ruhákat, ezáltal megfékezve az esetleges szabálytalanságokat.

\subsubsection{Nike Vaporfly Next\% futócipő (2019)}

2019 október 12-én Bécsben Eliud Kipchoge megdöntötte a maratonfutás világcsúcsát azzal, hogy első emberként 2 órán belül (1.59.40.) futotta le a 42195 méteres távot. A világcsúcs azonban több tényező miatt sem lett hivatalos. Egyrészt Kipchoge nem egy verseny keretében futotta a távot, hanem segítőivel, úgynevezett nyulakkal segítette a csúcsdöntését. Másrészt hatalmas vitát váltott ki a futó által viselt „csodacipő”, amely talpának az összetételével és kialakításával akár öt százalékot is hozzáadhat a futó teljesítményéhez. 2017-ben a Monza-i Formula 1-es versenypályán „steril” körülmények között (nézők és szurkolók nélkül), valamint a „csodacipő” hiányában 25 másodperccel kikerült a 2 órás álomhatárból. A szakértők véleménye szerint a NIKE cipője a talpában található karbonlemezek és a hab egyvelegével a készítők olyan hatást értek el, mintha a használója minden egyes lépésnél egy mini dobbantón lépkedne. Természetesen meg kell említeni, hogy a cipő használata önmagában nem elegendő ilyen teljesítményre [22].

\section{Anyag és módszer}

A szekunder kutatásom során a téma szakirodalmának feldolgozásánál a kutatási területhez szorosan illeszkedő nemzetközi és hazai kutatásokat, jelentéseket, szakkönyveket és tudományos közleményeket vizsgáltam. A szakirodalmi áttekintés során a szakterület neves nemzetközi és hazai kutatóinak a munkáit gyűjtöttem össze, rendszereztem és elvégeztem ezek értékelő összehasonlító elemzését. A statisztikai adatok, jelentések összegyűjtése során a vizsgált sportágak szakszövetségeinek az oldalait használtam, míg a nemzetközi adatok a STATISTA online adatbázisából származnak. A szakcikkeket, tanulmányokat a SCHOLAR és a SCOPUS kereső adatbázisok segítségével értem el. A primer kutatás keretein belül kvantitatív kutatást végeztem. Az itt kapott eredményeket összevetettem a szekunder kutatás során kapott eredményekkel. A következőkben a szekunder és primer kutatásom során használt módszereket ismertetem részletesen.

A primer vizsgálatom során kérdőíves megkérdezést alkalmaztam. A kutatás során összesen 1200 kérdőívet töltettem ki a 2017. szeptember és október közötti időszakban. A kitöltött kérdőívek beérkezését követően a kérdőívek rendszerezése történt meg, hogy kizárásra kerüljenek az érvénytelen, rosszul kitöltött kérdőívek. Ezt követően az elemzéshez felhasznált végleges elemszám 1006 darab lett.

Az értékelhető kérdőívek számítógépre történő bevitele és feldolgozása során Microsoft Office Excel 2016-os programot, a vizsgálatra IBM SPSS Statistics 22.0 szoftvert használtam.

A kutatás nem minősül reprezentatívnak, a válaszadók kiválasztása önkényes mintavétellel történt. A kérdőíves megkérdezés személyes megkeresés útján valósult meg. A vizsgálat alapvető célja annak bemutatása volt, hogy a kitöltőknek milyen kapcsolata van a sporttal, milyen típusú 
sportágak iránt érdeklődnek és jellemzően miért pont azokat a szakágakat követik figyelemmel.

A kérdőív kitöltése során a válaszadók a sporttal való kapcsolatuk jellemzésére több választ is megjelölhettek. Külön megkérdeztem az aktív és passzív sportfogyasztási szokásaikat. Az 1006 fó közül 891 fő számít vagy aktív vagy passzív vagy mindkét típusú sportfogyasztónak. 115 fő volt a mintában, aki nem sportfogyasztó. Nekik nem kellett kitölteni a kérdőíveket, csak a demográfiai adataik kerültek felmérésre.

A válaszadók nemére vonatkozóan elmondható, hogy a megkérdezettek 43\%-a (430fó) férfi, míg 57\%-a (576 fó) nő volt. A megkérdezettek életkor szerinti megoszlását tekintve megállapítható, hogy nagy mennyiségben van jelen a 19-30 év közötti korosztály (930 fő). Ennek oka a mintavételezés módja, mivel az országos mintavételre tett kísérlet sikertelen volt, így főként a Debreceni Egyetem hallgatói közül kerültek ki a kérdőív kitöltői. Iskolai végzettég alapján elmondható, hogy a korosztályi megoszlásnak megfelelően a legtöbb kitöltőnek középfokú végzettsége van, amely azzal magyarázható, hogy a válaszadók többségét egyetemisták alkották. A mintában 81\% (811 fő) középiskolai érettségivel, míg 8\% (85 fô) valamilyen felsőfokú szakképzettséggel rendelkezik. 6\% vagyis 63 fő alapfokú, és 1,5\% (15 fô) mesterfokú diplomával rendelkezik. 1\% (7 fő) kitöltő tudományos fokozattal rendelkezik.

Aktív sportfogyasztás tekintetében megállapítható, hogy 185 fő versenyszerűen, 271 fő szabadidőben sportol. 76 fő szeretne sportolni, de valami akadályozza benne. Az adatokat az 1 . ábra szemlélteti. Passzív sportfogyasztás tekintetében 306-an követik a médiában a sportokat, és 188-an járnak sportrendezvényre. Fontos megjegyezni, hogy mivel több választ is megjelölhettek a válaszadók, így lehet átfedés a helyszíni és a médiában történő fogyasztók között. 47 fő nyilatkozta azt, hogy egyáltalán nem érdeklődik a sport iránt. A passzív sportfogyasztással kapcsolatos adatokat a 2. ábra szemlélteti.

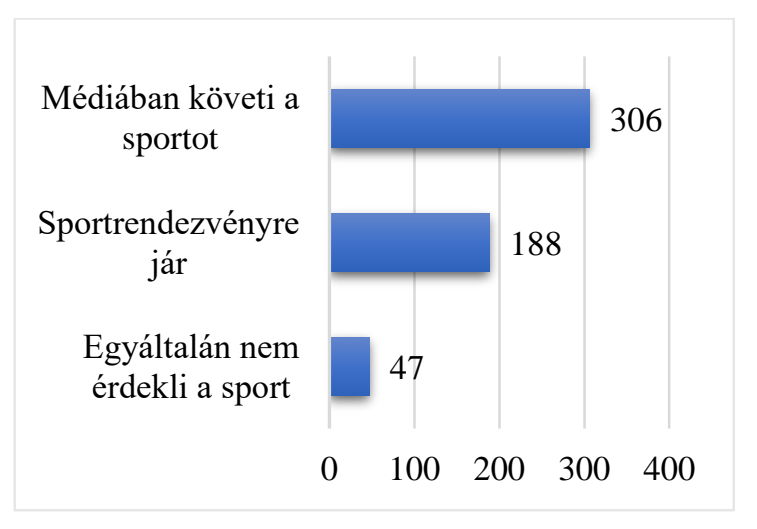

1. ábra: Aktív-passzív sportfogyasztók a mintában

Forrás: Saját adatbázis (2018)

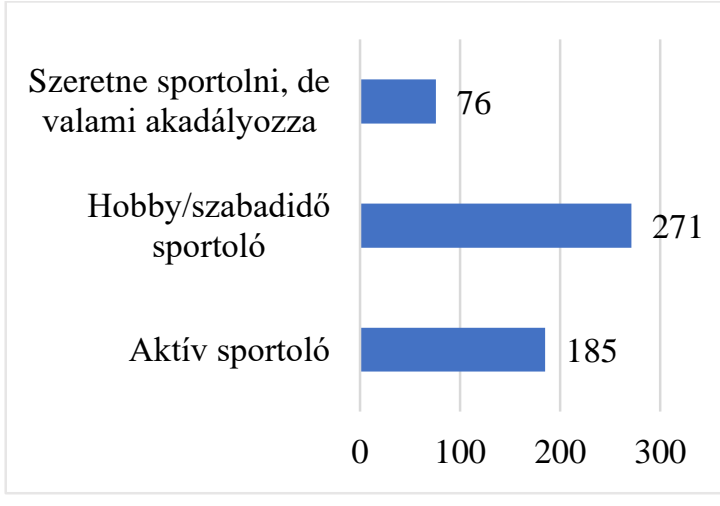

2. ábra: Passzív sportfogyasztók a mintában

Forrás: Saját adatbázis (2018)

\section{Eredmények}

Az úszás sportágban a cápadressz használata során 2008 és 2010 között közel 100 világrekord született. A 2008-as pekingi olimpia sikeres volt azok számára, akik az LZR Racer ruhát viselték, 
hiszen az összes úszási verseny 94\% -át ebben az úszóruhában nyerték a sportolók [23]. A pekingi olimpián elnyert úszásérmek $98 \%$-át a ruhát viselő úszók nyerték. Ha megvizsgáljuk az úszók 50 méteres medencéjében született világcsúcsok számát 2000 és 2019 között láthatjuk, hogy a 2008/2009-es évben a sportolók kiemelkedően szerepeltek. A 2010-ben történt betiltás következtében a következő 2 évben mindössze 2 világcsúcs született, amely bizonyíthatja a cápadressz teljesítményfokozó hatását. Az adatokat a 3. ábra szemlélteti.

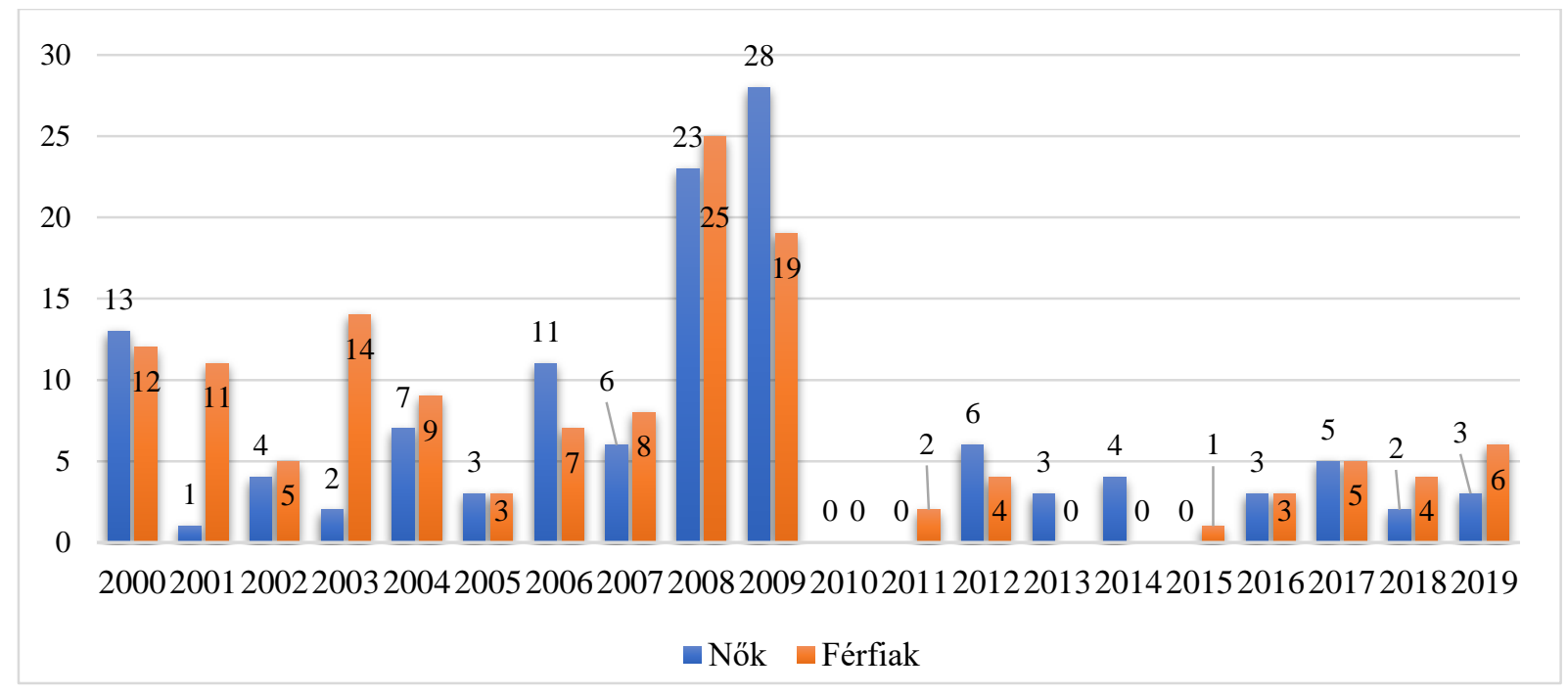

3. ábra: A megszerzett világcsúcsok száma úszásban, 50 méteres medencében (2000-2019)

Forrás: Saját szerkesztés (2019) a FINA adatbázisa alapján

Megvizsgálva a legnagyobb befolyással bíró sportolót az úszás történetében azt tapasztalhatjuk, hogy a cápadressz korszak egyik legismertebb úszója az amerikai Michael Phelps, aki pályafutása során összesen 23 olimpiai aranyérmet szerzett. Ha a statisztikákat vizsgáljuk ezzel a 28 aranyéremmel olyan országokat előz meg, mint Jamaica vagy Csehország. Elképesztő teljesítményének köszönhetően a legismertebb úszó a világon. Nettó értékét nagyjából 60 millió USD-ra becsülik [24].

A Nemzetközi Síszövetség (FIS) szabályozói azonban szeretnék elkerülni a túlzott távolságok hajszolását, ezért nem jegyeznek hivatalos távolsági világcsúcsot a síugró szakágban. Ettől függetlenül kevesen hitték, hogy az ugrók valaha is át fogják ugrani a 250 méteres távolságot, hiszen korábban lehetetlennek tűnt. 2017 márciusában Anders Fannamel 2015-ben felállított 251,5 méteres rekordját pár percen belül két ugró is felülmúlta. Először Robert Johansson, aki 252 métert ugrott az első körben, majd néhány perccel később Stefan Kraft is megdöntötte már az előbbi világcsúcsot, hiszen aki 253,5 m-re landolt, amely eredményével azóta is csúcstartó.

Egyes tanulmányok ismertették, hogy több elitfutó már 2016-ban is használta a Vaporfly futócipőt, de igazán nagy ismertséget az első két órán belüli maratonfutás kísérlete hozta meg a termék számára [25]. A Nike a 2017-es Breaking-2 projekt részeként kifejlesztette a VaporFly 4\% -os versenycipőt. A VaporFly névben szereplő 4\% -os megjelölés, valamint az elit és szabadidős futók eredményei azt jelzik, hogy a cipő 4\% -os előnyhöz juttatja a futót a különböző márkákkal szemben [26]. A korábban már ismertetett Kipchoge, Lelisa Desisával és Zersenay Tadessével 
együtt 2017-ben Monzában próbálta meg először a lehetetlennek tűnő kétórás szintidőt átlépni. Bár akkor minimális mértékben elmaradt a csúcsdöntés sokan méltatták a cipő kialakításában rejlő lehetőségeket. Sokan csak reklámfogásnak ítélték meg, azonban a megalkotott új verzió a Vaporfly Next\% már 5\% előnyt biztosít a futónak, amely olyan mértékű segítséghez lehetne hasonlítani, mintha a futók folyamatosan egy 1-1,5\%-os leejtőn futnának [27].

A kérdőíves vizsgálatban szereplő megkérdezettek közül (891 fő) 533 fő, 60\% nyilatkozta azt, hogy valamilyen mértékben egyetért azzal az állítással, hogy a sikeres sportolót megszépíti a teljesítménye, ezáltal feltételezhetően nagyobb mértékben követi az adott sportág eseményeit. A kiemelkedő teljesítménnyel bíró sportolók egyfajta véleményvezérek (opinion leader), akik olyan befolyásos személyek, akik az információkat másoknak továbbadják [28]. Jelenlétük az egyes sportágak népszerűsítése során elengedhetetlen. A híres, kiemelkedő eredményekkel rendelkező sportolók megnyilvánulásai befolyásolják a mintában található korosztály véleményét, és sok esetben a személy iránti szimpátia az, amely meghatározza a sportági hovatartozás mértékét. A részletes adatokat a 4. ábra szemlélteti.

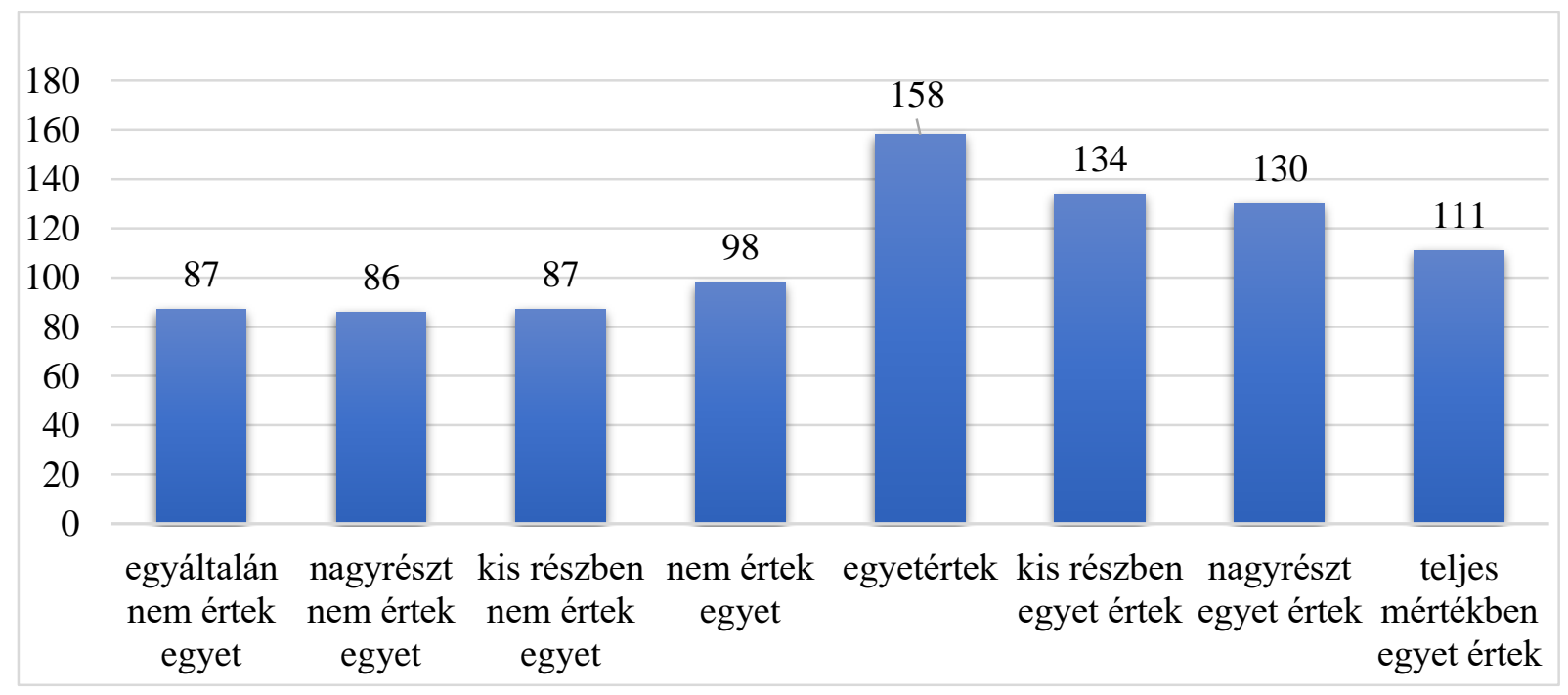

4. ábra: A sikeres sportolót vonzónak találom (megszépíti a teljesítménye) ( $N=891$ fó)

Forrás: Saját adatbázis (2018)

A stoplis cipő ahogy a szakirodalmi áttekintésben is szerepelt az 1954-es labdarúgó világbajnokságnak köszönhetően a sportolók körében óriási népszerűségre és ezáltal gazdasági sikerre is szert tett. De nem szabad különválasztani a gazdasági sikert, ami a termékek eladásából keletkezett a gyártók számára a sportszakmai sikerektől, amelyek a cipőknek (is) betudhatóak. A megannyi kiemelkedő teljesítmény, amit a csavaros cipő óta a futballpályán láthatunk, kétségkívül nem valósulhatott volna meg e termékfejlesztés nélkül. Mára a három legnagyobb sportszergyártó (NIKE, ADIDAS, PUMA) évi 37,55 milliárd USD bevételt generál csak a stoplis cipők piacán [29]. Az 5. ábra szemlélteti a gyártók bevételének alakulását 2010-2018 között. 


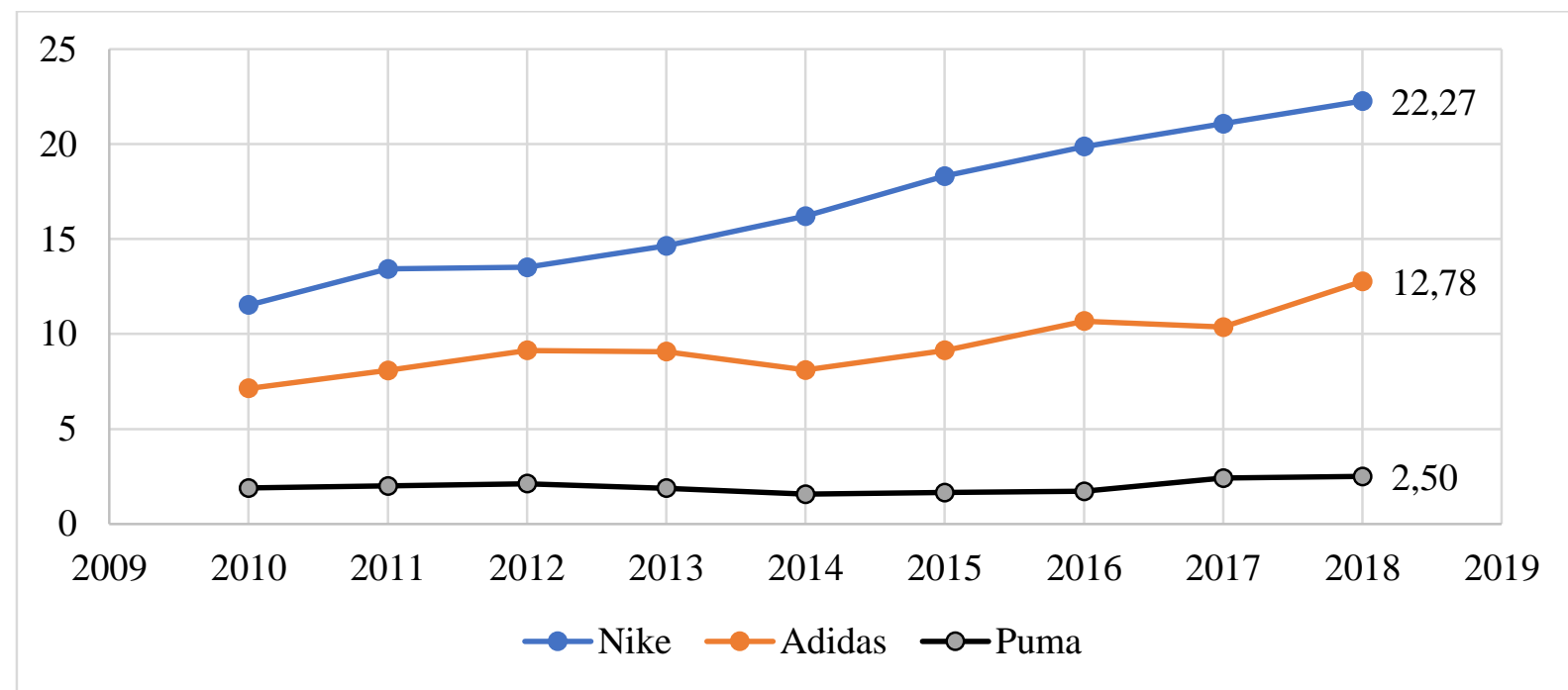

5. ábra: A Nike, az Adidas és a Puma lábbeli szegmensének bevétele 2010 és 2018 között (milliárd USD)

Forrás: STATISTA (2019)

\section{Következtetések és összefoglalás}

A sport az utóbbi évtizedekben egyre inkább a szórakoztató-ipar szerves részévé válik. Önálló iparágként a versenyelőny kialakításához és megőrzéséhez innovációs tevékenységeket kell eszközölniük a sportági szereplőknek, ha fel akarják venni a versenyt a más szabadidős tevékenységekkel (televízió, mozi, színház stb.). A versenyképességi vizsgálatok során kiderült, hogy a hivatásos sportban a szórakoztató faktor központi kérdéssé vált, ezáltal a sportban kiélezett verseny zajlik a fogyasztók idő- és pénzráfordításáért, illetve az üzleti szféra figyelméért. Nem elhanyagolható szempont azonban az sem, hogy a fogyasztókon túl fontos az állam szervezeti, jogi és pénzügyi támogatásának megszerzése is. A kormányzat sportiparban történő szerepvállalása alapjaiban határozhatja meg az adott ország sportiparágának működését. A vizsgálat során kapott eredmények felhasználásával megállapítható, hogy a különböző vizsgált innovációs sporteszközök valamennyi sportágban előidéznek/előidéztek teljesítménynövekedést, amely sportszakmai sikerként könyvelhető el. A sportolók kiemelkedő sportági eredményessége elősegíti a véleményvezérek (sikeres sportolók) megjelenését a sportágakban. A kapott eredmények elemzése során megállapítható, hogy a vizsgálatban szereplő sportfogyasztók számára a kiemelkedő eredményességű sportolók vonzó egyéniségekké vállhatnak a sportteljesítményük által, amelynek következtében szélesebb nézőközönséget érhetnek el. Az innováció során létrejövő új termékek értékesítéséből származó bevételek elemzése során megállapítható, hogy azok jelentős bevételt generálnak a sportszergyártóknak, amely így sportgazdasági eredményességként könyvelhető el. Megállapítható tehát, hogy a sportszergyártók hatalmas profitra tesznek szert azzal, ha a sportolók a saját gyártású eszközeikkel érik el a sikereiket!

A tanulmány létrejötte az EFOP-3.6.2-16-2017-00003 Sport- Rekreációs - és Egészséggazdasági Kooperációs Kutatóhálózat létrehozása címú pályázat támogatásával valósult meg. 


\section{Felhasznált irodalom}

[1] Madarász, T. (2018): Magyar sportsikerekben gazdag egyéni sportágak versenyképességi tényezőinek meghatározása fiatal sportfogyasztók megítélése alapján (Doktori disszertáció, Debreceni Egyetem).

[2] Muszbek M. (2016): Sportgazdasági kihívások a mai magyar sportban, MKT 54. Közgazdászvándorgyülés - Kecskemét

[3] Chikán A. (2006): A vállalati versenyképesség mérése. Pénzügyi Szemle, Volume 51, Nr. 1, 42-57. o.

[4] Lengyel I. (2000a): A regionális versenyképességről. Közgazdasági Szemle, XLVII. évf., december, 962-987. o.

[5] Czakó E. (2000): Versenyképesség iparágak szintjén -a globalizáció tükrében - PhD disszertáció. Budapesti Közgazdaságtudományi és Államigazgatási Egyetem, Budapest. 202 p.

[6] Jámbor A. (2008): A versenyképesség elmélete és gyakorlata. Bulletin of the Szent István University Special Issue Part I. Gödöllő. 18 p.

[7] Latruffe L. (2010): Competitiveness, productivity and efficiency in the agricultural and agrifood sectors

[8] Porter M. E. (1993): Versenystratégia, Akadémiai Kiadó, Budapest

[9] Chikán A. (2009): A közgazdaságtudomány és a magyar sport - egy elemzési keret. Sporttudományi konferencia, 2009. október 9., MTA, Budapest.

[10] Stocker M. - Szabó Á. (2011): A nemzetgazdasági versenyképesség sportszakmai és gazdasági aspektusai. Műhelytanulmány, BCE Vállalatgazdaságtani Intézet, Budapest

[11] Ács P. (2007): A magyar sport területi versenyképességének vizsgálata többváltozós statisztikai módszerekkel, Tér és Társadalom 21. évf. 2007/2. 117-126. p.

[12] András K. (2011): A hivatásos labdarúgás múködési modellje. Magyar Sportudományi Füzetek III. - Sportágak versenye, 18-42. o.

[13] András K. (2002): Üzleti elemek a sportban. BCE Gazdálkodástani Doktori Iskola, doktori értekezéstervezet

[14] János, P., - Gábor, P. (2006): Innováció menedzsment kézikönyv. Magyar Innovációs Szövetség, Budapest, 22.

[15] Yamashita H. (1998): Competitiveness and corporate culture. Ashgate Publishing.

[16] Csath M. (2010): Versenyképesség-menedzsment. Nemzeti Tankönyvkiadó. Budapest

[17] Hoványi G. (2002): A menedzsment új horizontjai [The new horizons of management]. Közgazdasági Szemle (Economic Review-monthly of the Hungarian Academy of Sciences), 49 (3), 251-264.

[18] Collignon H. - Sultan N. (2014): Winning in the Business of Sports. AT Kearney, 1.

[19] Ráthonyi, G. - Müller A. - Rathonyi-Odor K. (2018): How Digital Technologies Are Changing Sport? APSTRACT: Applied Studies in Agribusiness and Commerce, 12 (1033-2019-3296), 89-96. 
[20] Borbély A. - Ráthonyi-Ódor K. (2015): Sportökonómia, Campus Kiadó, Debrecen, 166 p., ISBN: 9789639822399

[21] Drašinac, G., Karninčić, H., Jašić, D., \& Burger, A. (2015). Environmental Success Factors or the Justififi cation for the Prohibition of High-Tech Swimsuits in Swimming. Collegium antropologicum, 39(Supplement 1), 181-184.

[22] Kipchoge breaks two-hour barrier in Vienna: https://worldathletics.org/news/report/eliud-kipchoge-breaks-two-hours-vienna Letöltve: 2019. 10. 27.

[23] Time's Best Innovations of 2008: Time.com (29 October 2008). http://content.time.com/time/specials/packages/completelist/0,29569,1852747,00.html Letöltve: 2019. 10. 27.

[24] Michael Phelps total net worth: https://www.celebritynetworth.com/richestathletes/olympians/michael-phelps-net-worth Letöltve: 2019. 10. 27.

[25] Longman J. (2017): Do Nike's New Shoes Give Runners an Unfair Advantage? https://www.nytimes.com/2017/03/08/sports/nikes-vivid-shoes-and-the-gray-area-ofperformance-enhancement.html Letöltve: 2019. 10. 27.

[26] Reynolds G. (2018): Nike Vaporfly 4\% shoe may make some run faster. New York Times, 5 december 2018., https://www.nytimes.com/2018/12/05/well/move/nike-vaporfly-4shoe-may-make-some-run-faster.html?searchResultPosition=1. Letöltve: 2020. 01. 14.

[27] Guinness J. - Bhattacharya D. - Chen J. - Chen M. - Loh A. (2020): An Observational Study of the Effect of Nike Vaporfly Shoes on Marathon Performance. arXiv preprint arXiv:2002.06105.

[28] Chelladurai P. - Saleh S. D. (1980): Dimensions of leader behavior in sports: Development of a leadership scale. Journal of sport psychology, 2(1), 34-45.

[29] Revenue from footwear segment of Nike, Adidas and Puma from 2010 to 2018: https://www.statista.com/statistics/278834/revenue-nike-adidas-puma-footwearsegment/ Letöltve: 2019. 10. 27. 